\title{
ANALISIS KEJADIAN EFEK SAMPING OBAT PADA PASIEN TB/HIV KO- INFEKSI DI RUMAH SAKIT UMUM PERSAHABATAN JAKARTA
}

\author{
Dessy Hera Setiawati, Syamsudin, Hesti Utami dan Heidy Agustin \\ Universitas Pancasila, Jakarta Selatan, Indonesia \\ Email: dessyherasetiawati@gmail.com, syamsudin.abdillah@gmail.com, \\ hesty.p@gmail.com dan heidy.agustin@gmail.com
}

\begin{abstract}
Tuberculosis is an opportunistic infection that often occurs in HIV infections TB / HIV co-infection is an infectious agent that causes high mortality in the world. Comsumption of OAT/ART together will increase the incidence of side effects of drugs that can be affected by demographic, social, drugs and disease factors. This study aims to find out the risk factors for drug side effects with probabilities very likely to occur in TB / HIV co-infected patients at the Persahabatan Hospital in Jakarta. This study was an observational study with cross sectional design Purposive sampling methode this used to collect the sample. There were $42 \mathrm{~TB} / \mathrm{HIV}$ co-infection patients assessed during the study. It was found that the side the most common side effects of the drug were neuropathy $(n=30 ; 69,8 \%)$, nausea / vomiting $(n=27 ; 62,8 \%)$, skin rash $(n=26 ; 60.5 \%)$, fatigue $(n=25 ; 58,1 \%)$ and headache $(n=23 ; 53,3 \%)$ Based on the Naranjo scale the occurrence of side effects with very likely probability were gynecomastia $(n=1 ; 100 \%)$, skin discoloration $(n=14$; $66,7 \%)$, skin rash ( $n=15 ; 65,2 \%)$, hearing loss and depression $(n=9 ; 60 \%)$.
\end{abstract}

Keywords: co-infections; TB/HIV; risk factor; side effects OAT/ART

\begin{abstract}
Abstrak
Tuberkulosis merupakan infeksi oportunistik yang banyak terjadi pada infeksi HIV. TB/HIV ko-infeksi merupakan agen infeksius yang menyebabkan mortalitas tinggi di dunia. Konsumsi OAT/ART secara bersama akan meningkatkan kejadian efek samping obat yang dipengaruhi oleh faktor demografi, sosial, faktor obat dan penyakit. Tujuan penelitian ini untuk mengetahui faktor resiko efek samping obat dengan probabilitasnya. sangat mungkin terjadi pada pasien ko-infeksi TB/HIV di Rumah Sakit Umum Persahabatan Jakarta yang mengkonsumsi OAT/ART. Metode penelitian ini menggunakan penelitian observasional dengan design cross sectional metode purposive sampel digunakan untuk pengumpulan data. Sebanyak 42 pasien TB/HIV ko-infeksi di Rumah Sakit Persahabatan Jakarta mengalami efek samping obat yang paling sering terjadi yaitu neuropati $(n=30 ; 69,8 \%)$, mual/muntah $(n=27$; $62,8 \%)$, ruam kulit $(\mathrm{n}=26 ; 60,5 \%)$, kelelahan $(\mathrm{n}=25 ; 58,1 \%)$ dan sakit kepala $(\mathrm{n}=23 ; 53,3 \%)$. Berdasarkan skala Naranjo dengan kejadian efek samping yang probabilitasnya sangat mungkin terjadi adalah ginekomastia $(n=1 ; 100 \%)$, perubahan warna kulit $(\mathrm{n}=14 ; 66,7 \%)$, ruam kulit $(\mathrm{n}=15 ; 65,2 \%)$, gangguan pendengaran dan depresi $(n=9 ; 60 \%)$.
\end{abstract}


Dessy Hera Setiawati, Syamsudin, Hesti Utami dan Heidy Agustin

Kata kunci: ko-infeksi; tb/hiv; faktor resiko; efek samping obat; oat/art

Coresponden Author

Email: dessyherasetiawati@gmail.com Artikel dengan akses terbuka dibawah lisensi

\section{Pendahuluan}

Tuberkulosis dan HIV/AIDS merupakan penyebab utama infeksi penyakit di Negara berkembang yang disebabkan oleh dua patogen yaitu Mycobaterium tuberculosis dan HIV (Human Immunodeficiency Virus) dimana saling potensial antara satu dan yang lain, fungsi imunitas menurun dan menyebabkan kematian apabila tidak terobati secara tepat (Bruchfeld, Correia-Neves, \& Källenius, 2015).

TB-HIV merupakan masalah utama kesehatan global dan penyakit infeksi yang dapat menyebabkan kematian. Pada tahun 2015 diperkirakan sebanyak 400 ribu orang mengidap ko-infeksi TB /HIV yang menyebabkan kematian, dimana pada setiap tahunnya bertambah 1,4 juta orang yang meninggal yang disebabkan oleh TB itu sendiri dan 800 ribu orang dapat menyebabkan kematian yang disebabkan oleh HIV itu sendiri. Global tuberculosis control pada tahun 2015 diperkirakan 10,4 juta kasus baru dengan TB aktif diseluruh dunia dan tercatat kasus ko-infeksi TB-HIV sebanyak 55\% (World Health Organization, 2015).

Prevalensi kejadian ko-infeksi TB/HIV pada tahun 2015 terjadi di Sub-sahara Afrika sebanyak 295.000 jiwa, Asia Tenggara 74.300 jiwa, Amerika 5.890 jiwa, Eropa 4.870 jiwa. Secara global pada tahun 2015 55\% pasien TB dengan HIV terbesar berada di wilayah Afrika 81\%. Perkembangan epidemi HIV di Indonesia termasuk yang tercepat di Asia. Hasil survei membuktikan bahwa prevalensi HIV dengan TB di beberapa provinsi pada tahun 2006 sebanyak 2\% di Jogyakarta sedangkan pada tahun 2008 prevalensi TB/HIV 0,8\% di Jawa Timur, 3,8\% di Bali dan 14\% di Papua (who, 2015), (Getahun, Gunneberg, Granich, \& Nunn, 2010).

Sejalan dengan meningkatnya kasus TB, WHO mengembangkan strategi pengendalian TB yang dikenal sebagai DOTS (Directly Observed Treatment Shortcourse). Peningkatan kasus TB pada ODHA akan meningkatkan risiko penularan TB pada masyarakat dengan atau tanpa terinfeksi HIV. Pencegahan HIV terkait TB melebihi pelaksanaan sepenuhnya dari DOTS, karena juga mencakup pencegahan infeksi HIV sejak awal, pencegahan berkembangnya infeksi TB laten menjadi penyakit aktif serta ketentuan dan penyediaan pengobatan dan perawatan HIV sehingga penggobatan tersebut dapat menurunkan dan meminimalkan infeksi TB dan HIV (Getahun, Gunneberg, Granich, \& Nunn, 2008).

Pengobatan HIV dengan menggunakan ART (NRTI/NNRTI) diterapi kombinasi dengan OAT. Selama pemakaian obat tentu saja dapat menimbulkan efek samping obat seperti hepatoksisitas (43\%), gangguan pencernaan (31\%), reaksi alergi (16,3\%), arthragia $(19,5 \%)$ dan gangguan neurologi $(14,3 \%)$. Efek samping obat yang dialami 
pasien tidak hanya tergantung pada karakteristik pasien saja tetapi juga tergantung terhadap penyakit penyerta lainnya karena setiap individu memiliki sensitivitas di dalam tubuhnya yang berbeda-beda. Efek keparahan dari efek samping obat sangat bervariasi antara pasien satu dengan yang lainnya. Berbagai faktor dapat mempengaruhi seperti polifarmasi, faktor usia, faktor penyakit dan faktor genetic (Agustya, Putra, \& Putra, n.d.).

Penelitian ini dilakukan di Rumah Sakit Umum Persahabatan Jakarta yang merupakan salah satu Rumah Sakit rujukan Paru pada tahun 2017 penyakit TB itu sendiri termasuk dalam penyakit 3 besar terbanyak di RSU Persahabatan Jakarta. Penilaian dari efek samping obat yang terjadi dengan menggunakan skala Naranjo. Sebelumnya penelitian yang dilakukan Natalie di RSUP dr.Karyadi mengenai JenisJenis Efek Samping OAT dan ART. Diharapkan dengan diketahuinya efek samping obat pada pasien TB/HIV ko-infeksi yang menggunakan obat OAT/ART yang dianalisis menggunakan skala Naranjo para tenaga medis khususnya dokter spesialis menjadi lebih waspada dan sebagai tenaga farmasi semakin gencar edukasi pasiennya terlebih pasien yang memiliki karakteristik terhadap TB/HIV ko-infeksi.

\section{Metode Penelitian}

Penelitian ini merupakan penelitian observasional dengan pendekatan crosssectional dengan mencari hubungan antara variabel independen (faktor sosial, faktor obat dan faktor penyakit) dan variabel dependen (efek samping obat) pada pasien TB/HIV ko-infeksi di Rumah Sakit Umum Persahabatan Jakarta. Efek samping obat dilihat berdasarkan skala Naranjo. Penilaian efek samping obat dilakukan oleh peneliti, dokter spesialis paru dan dokter spesialis penyakit dalam di RSU Persahabatan Jakarta.

Penelitian ini dimulai dengan penentuan populasi dan sampel secara prospektif pada pasien rawat jalan. Penentuan jumlah sampel dilakukan dengan perhitungan sesuai dengan perhitungan rumus besarnya sampel menggunakan hipotesis studi Crosssectional (Slovin).

$$
\mathrm{n}=\frac{\mathrm{N}}{1+\left(\mathrm{Nx} \mathrm{e}^{2}\right)}
$$

Peneliti menetapkan kriteria inklusi dan ekslusi sampel, kemudian mengumpulkan sampel dengan metode purposive sampling, dimana metode ini dipilih sesuai dengan kriteria yang ditetapkan oleh peneliti. Perlakuan sampel dilakukan penelusuran rekam medik, melakukan wawancara dan pengisian kuesioner yang berisi beberapa yang telah dilakukan uji validasi dan reliabilitas.

Penelitian dan pengolahan data dilakukan selama tiga bulan (Juli 2018- September 2018). Kemudian analisa data secara bertahap yaitu univariat, bivariat dan multivariat. Data univariat akan disajikan secara deskriptif dengan penjelasan hasil penelitian yang ditampilkan dalam bentuk tabel. Sedangkan data bivariat dan multivariat akan disajikan dari hasil Analisa statistik. 
Dessy Hera Setiawati, Syamsudin, Hesti Utami dan Heidy Agustin

\section{Hasil dan Pembahasan}

\section{A. Karakteristik Sosiodemografi Pasien Tb/Hiv Ko-Infeksi}

Dampak pandemik HIV di dunia akan menambah permasalahan Tuberkulosis. Ko-infeksi TB dengan HIV merupakan tantangan terbesar dalam menghadapi kedua infeksi tersebut. Kedua penyakit ini dan penyebabnya saling berinteraksi begitupula dalam pemberian terapi sehingga diperlukan penelitian untuk mengetahui kejadian efek samping obat yang terjadi. Untuk melihat karakteristik sosiodemografi dapat dilihat pada tabel V.1.

Distribusi pasien berdasarkan data sosiodemografi menunjukkan bahwa sebanyak 42 pasien TB/HIV ko-infeksi yang mengkonsumsi OAT/ART sebanyak 27 orang $(62,8 \%)$ berjenis kelamin pria dan 15 orang $(34,9 \%)$ berjenis kelamin wanita. Beberapa penelitian yang lain juga menunjukkan hasil yang sama seperti di RSUP. DR. Kariadi Semarang bahwa presentase jenis kelamin pria lebih besar $(71,7 \%)$ daripada presentase jenis kelamin wanita $(28,9 \%)$. Hasil yang sama juga ditemukan pada penelitian yang dilakukan di RSUD Buleleng presentase berjenis kelamin pria lebih dominan $(68,8 \%)$ daripada presentase wanita sebesar $(31,4 \%)$. Sedangkan berdasarkan usia pasien TB/HIV ko-infeksi dibagi menjadi 2 kelompok yaitu kelompok usia 18-30 tahun sebanyak 8 orang (19\%) dan kelompok usia 31-60 sebanyak 34 orang (81\%) dengan rata-rata usia adalah 39 tahun. Penelitian di RSUD buleleng menunjukkan bahwa presentase terbesar yaitu kelompok usia 35- 60 tahun (80\%) (Human \& Virus, 2011),(Natalie, Kholis, \& Ngestiningsih, 2016).

Sosiodemografi berdasarkan tingkat pendidikan pada pasien TB/HIV koinfeksi terlihat kelompok yang paling besar adalah dengan tingkat pendidikan SMA sebanyak 21 orang $(48,8 \%)$, SMP sebanyak 11 orang $(12,6 \%)$ kemudian SD dan Perguruan Tinggi sebanyak 5 orang (11,6\%). Presentase dari jenis pekerjaan menunjukkan pasien dengan pekerjaan buruh sebanyak 15 orang $(34,9 \%)$, ibu rumah tangga sebanyak 14 orang (32,6\%), pegawai swasta

sebanyak 11 orang $(25,6 \%)$ dan PNS sebanyak 2 orang $(4,7 \%)$. Status pernikahan terlihat kelompok yang paling besar adalah dengan status pernikahan menikah sebanyak 34 orang $(79,1 \%)$ dan sebanyak 8 orang $(18,6 \%)$ dengan status pasien belum menikah. Paparan terjadinya HIV menunjukkan bahwa paparan secara seksual sebanyak 29 orang $(67,4 \%)$ diikuti dengan IDU sebanyak 10 orang $(23,3 \%)$ dan penggunaan jarum suntik dan transmisi sekual secara bersamaan sebanyak 3 pasien (7,0\%). Berdasarkan penelitian VCT yang dilakukan oleh UGM Yogyakarta menyebutkan bahwa tingginya kejadian HIV/AIDS disebabkan oleh faktor biologis wanita yang memiliki risiko terpapar dari suami yang melakukan seks tanpa menggunakan kondom (No Title, 2012).

Karaktersitik pasien TB/HIV ko-infeksi berdasarkan Jumlah CD4 pada pasien TB/HIV ko-infeksi di RSU Persahabatan Jakarta menunjukkan sebanyak 11 pasien $(26,19 \%)$ mengalami imunodefisiensi berat CD4 $<200 \mathrm{sel} / \mathrm{mm} 3$ dimana mengindikasikan sistem kekebalan tubuh yang menurun sehingga 
patogen penyebab infeksi dapat masuk secara bersamaan. 26 pasien $(61,9 \%)$ dan 5 pasien (11,9\%) mengalami imunodefisiensi sedang (200-349 sel/mm3) ringan (350-499sel/mm3). Sebanyak 17 pasien (40,5\%) dengan HBsAg positif. Hasil pemeriksaan BTA menunjukkan bahwa sebanyak 18 responden dengan pemeriksaan BTA positif (41,9\%) dan sebanyak 24 orang responden menunjukkan hasil pemeriksaan BTA negatif $(55,8 \%)$. Berdasarkan penelitian yang dilakukan Saroso menyebutkan bahwa rata-rata pemeriksaan BTA pasien yang diperoleh adalah negatif ini dapat disebabkan oleh menurunnya imunitas seseorang sehingga akan mempengaruhi gambaran bakteriologis pada pasien TB/HIV ko-infeksi (Infeksi et al., 2015).

\section{Tabel 1}

Sosiodemografi pasien TB/HIV ko-infeksi di RSU Persahabatan Jakarta

\begin{tabular}{|c|c|c|c|}
\hline No & Variabel & n (42) & Presentase (\%) \\
\hline \multirow[t]{3}{*}{1.} & Usia & & \\
\hline & 18-30 tahun & 8 & 18,6 \\
\hline & 31-60 tahun & 34 & 79,1 \\
\hline \multirow[t]{3}{*}{2.} & Jenis kelamin & & \\
\hline & Pria & 27 & 62,8 \\
\hline & Wanita & 15 & 34,9 \\
\hline \multirow[t]{5}{*}{3.} & Jenis pekerjaan & & \\
\hline & Ibu rumah tangga & 14 & 32,6 \\
\hline & Buruh & 15 & 34,9 \\
\hline & Pegawai swasta & 11 & 25,6 \\
\hline & PNS & 2 & 4,7 \\
\hline \multirow[t]{5}{*}{4.} & Tingkat Pendidikan & & \\
\hline & SD & 5 & 11,6 \\
\hline & SMP & 11 & 25,6 \\
\hline & SMA & 21 & 48,8 \\
\hline & PT & 5 & 11,6 \\
\hline \multirow[t]{3}{*}{5.} & Status pernikahan & & \\
\hline & Menikah & 34 & 79,1 \\
\hline & Belum menikah & 8 & 18,6 \\
\hline \multirow[t]{3}{*}{6.} & Hepatitis & & \\
\hline & $\mathrm{Ya}$ & 38 & 88,4 \\
\hline & Tidak & 4 & 9,3 \\
\hline \multirow[t]{3}{*}{7.} & BTA & & \\
\hline & Positif & 18 & 41,9 \\
\hline & Negatif & 24 & 55,8 \\
\hline \multirow[t]{4}{*}{8.} & Paparan HIV & & \\
\hline & Jarum suntik & 10 & 23,3 \\
\hline & Transmisi sexual & 29 & 67,4 \\
\hline & $\begin{array}{l}\text { Jarum suntik } \\
\text { transmisi sexual }\end{array}+$ & 3 & 7,0 \\
\hline
\end{tabular}




\section{B. Profil Efek Samping Yang Terjadi Pada Pasien Tb/Hiv Ko-Infeksi}

Semua pasien TB/HIV ko-infeksi mengalami kejadian efek samping obat OAT dan ART. Terdapat 235 kejadian efek samping obat yang paling banyak terjadi adalah neuropati, kaki terasa panas akibat neuropati perifer sensorik sebanyak 30 orang $(69,8 \%)$, diikuti dengan mual/muntah 27 pasien $(62,8 \%)$ dan kejadian efek samping lainnya dapat dilihat pada tabel 2.

\section{Tabel 2}

Kejadian efek samping obat yang terjadi di RSU Persahabatan Jakarta

\begin{tabular}{clcc}
\hline No & Jenis efek samping & Jumlah $(\mathrm{n}=42)$ & Presentase $(\%)$ \\
\hline 1 & Neuropati perifer & 30 & 69,8 \\
\hline 2 & Mual / muntah & 27 & 62,8 \\
\hline 3 & Ruam kulit & 26 & 60,5 \\
\hline 4 & Kelelahan & 25 & 58,1 \\
\hline 5 & Sakit kepala & 23 & 53,3 \\
\hline 6 & Perubahan warna kulit & 21 & 48,8 \\
\hline 7 & Pengelihatan kabur & 19 & 44,2 \\
\hline 8 & Diare & 18 & 41,9 \\
\hline 9 & Anemia & 14 & 32,6 \\
\hline 10 & Gangguan pendengaran & 12 & 27,9 \\
\hline 11 & Depresi & 11 & 25,6 \\
\hline 12 & Gangguan Tidur & 8 & 18,6 \\
\hline 13 & Ginekomastia & 1 & 2,3 \\
\hline
\end{tabular}

\section{Neuropati perifer}

Sebanyak 30 pasien $(69,8 \%)$ pasien mengalami neuropati perifer yang disebabkan oleh terapi OAT (Isoniazid, Etambutol dan Streptomisin). Penelitian sebelumnya yang dilakukan di RSUD Dok II Jayapura melaporkan bahwa efek samping obat yang terjadi sebagian besar yaitu neuropati perifer $(20,4 \%)$. (Irawati, Biologi, \& Papua, 2017), (Olowe, Makanjuola, Adekanmi, \& Adefioye, 2017).

Gejala neuropati perifer adalah mati rasa, kelemahan dan rasa terbakar di ekstremitas yang disebabkan oleh OAT dan multifaktorial lainnya seperti berat badan yang rendah, defisiensi nutrisi dan konsumsi alkohol. Neuropati perifer dapat menyebabkan masalah kesehatan jangka panjang yang dapat bersifat irreversible atau permanen dan sebagai penanganan dapat diberikan piridoksin. Mekanisme patofisiologi terjadinya neuropati perifer pada pasien TB/HIV koinfeksi menyebabkan Neurotoksik lainnya disebabkan oleh konsumsi OAT dan ART dimana glikoprotein mengaktivasi makrofag untuk melepaskan mediator inflamasi seperti TNF alfa dan IL-1. Glikoprotein juga menginduksi sel Schwann untuk melepaskan RANTES yang mana pada serabut saraf ganglion memproduksi TNF alfa sehingga menyebabkan kematian sel saraf/neurotoksik (Mafukidze, Calnan, \& Furin, 2016), (Robinson-papp, 2013). 


\section{Gastrointestinal}

Efek samping obat yang paling sering terjadi kedua pada pasien TB/HIV ko-infeksi yaitu gangguan gastrointestinal (mual, muntah, dispepsia, nyeri abdomen) sebanyak 27 pasien (62,8\%). Kejadian efek samping ini juga terjadi pada penelitian di Nigeria sebanyak 18 pasien dari 33 pasien (10\%) mangalami gangguan gastrointestinal umumnya karena konsumsi OAT selama 2 bulan pertama yaitu Pirazinamid. Pada penelitian di Nigeria pasien TB/HIV ko-infeksi yang menggunakan obat zidovudine membuktikan dapat meningkatkan kejadian efek samping obat terhadap gastrointestinal (51,85\%) pada pemberian OAT/ART selama 6-12 bulan $(\mathrm{P}=0,03 ; 0 \mathrm{R}=0,38)$, Pemberian 12-24 bulan $(\mathrm{P}=0,005 ; \mathrm{OR}=0,35)$. Zidovudin dikaitkan dengan toksisitas hematologis dan juga dapat mengganggu epitel usus yang berkembang pesat tetapi berdasarkan penelitian zidovudin dapat meningkatkan berat badan pada pasien TB/HIV koinfeksi, meningkatkan disfungsi pencernaan melalui dua mekanisme yaitu Imunitas yang dipulihkan dapat menyebabkan pembersihan patogen usus sekunder dan efek enteropatogenik dari HIV itu sendiri dapat diperbaiki.

Terapi AZT sering dikaitkan dengan anemia dan neutrapia yang mengindikasikan toksisitas sumsum tulang, sehingga dapat juga memiliki efek buruk pada epitel usus sebagai kompartemen sel yang berkembang lainnya. Penerima AZT mengalami penurunan aktivitas alkali fosfatase dibandingkan dengan kontrol. Temuan ini menunjukkan atrofi hiporegeneratif dari usus kecil dan kejenuhan enterosit yang terkait dengan infeksi HIV mikroba (Dean et al., 2002), (Eluwa, Badru, \& Akpoigbe, 2012).

\section{Ruam kulit}

Merupakan kejadian efek samping obat yang terjadi pada pasien TB/HIV ko-infeksi yang mengkonsumsi obat OAT/ART sebanyak 26 pasien $(60,3 \%)$ di RSU Persahabatan Jakarta. Berdasarkan studi didapat bahwa penggunaan obat OAT/ART seperti Rifampisin, Kotrimoksazol, Pirazinamid, Isoniazid, nevirapin dan efavirens dapat menyebabkan ruam kulit hingga sindrom Steven-Johnson (Michael, Sogaolu, Fehintola, Ige, \& Falade, 2016).

Reaksi hipersensitivitas ini dapat terjadi oleh beberapa faktor yaitu paparan obat OAT/ART, terapi profilaksis kotrimoksazol, faktor genetik, menurunnya sistem imun dimana distimulasi oleh HLA dan reseptor sel T, sel T infitrasi kulit CD4 mengsekresikan sitokin seperti IL-5, granzime, dan eotaksin sebagai pembentuk, membangun dan diferensiasi eosinofil. Obat dapat menstimulasi sel $\mathrm{T}$ dan mematikan sel autologous melalui perforin pathway sehingga menyebabkan ruam kulit (Pacific, 2014).

Penelitian lain yang dilakukan oleh Dean et al membuktikan bahwa ruam kulit merupakan efek samping obat masuk dalam tiga besar yang terjadi pada pasien TB/HIV ko-infeksi 31 pasien (17\%) pada dua bulan terapi awal. Obat yang menyebabkan ruam kulit terjadi yang di identifikasi yaitu sebanyak 29 kasus pasien dimana menggunakan terapi OAT (18 pasien) dan terapi ART (11 
pasien). Penelitian lain yang dilakukan di Nigeria membuktikan bahwa kejadian ruam kulit menduduki tiga besar dalam kejadian efek samping OAT/ART pada pasien TB/HIV ko-infeksi dimana sebanyak 19 pasien mengalami ruam kulit (Michael et al., 2016),(Dean et al., 2002).

\section{Kombinasi Obat Oat/Art}

Pasien TB/HIV ko-infeksi yang mendapatkan obat OAT/ART Kejadian efek samping obat yang terjadi dapat disebabkan karena penggunaan obat OAT dan ART secara bersamaan sehingga dapat menyebabkan interaksi obat yang potensial. Salah satu obat golongan OAT yang dapat menyebabkan kejadian interaksi obat potensial adalah rifampisin dan isoniazid merupakan komponen mayor dari kombinasi OAT yang diberikan pada pasien TB. Rifampisin dapat meningkatkan hepatotoksisitas dari INH, kombinasi ini tidak menyebabkan hepatotoksitas pada sebagian besar penderita akan tetapi tetap diperlukan monitoring hepatotoksisitas terutama bagi penderita penyakit hati dan penderita dengan asetilator lambat untuk isoniazid ( $\mathrm{Ag}$, n.d.).

Tabel 3

Jenis terapi OAT/ART yang digunakan pada pasien TB/HIV ko-infeksi di RSU Persahabatan Jakarta

\begin{tabular}{|c|c|c|}
\hline No & Jenis terapi & $\begin{array}{c}\text { Presentase } \\
(n=42)\end{array}$ \\
\hline \multirow[t]{4}{*}{1} & Terapi OAT & \\
\hline & RHZE & $23(53,5 \%)$ \\
\hline & $\mathrm{RH}$ & $8(18,6 \%)$ \\
\hline & RHZES & $11(25,6 \%)$ \\
\hline \multirow[t]{4}{*}{2} & Terapi ART & \\
\hline & Tenofovir+lamivudine+efavirenz & $33(76,7 \%)$ \\
\hline & Lamivudin+zidovudin+nevirapine & $8(18,6 \%)$ \\
\hline & $\begin{array}{l}\text { Tenofovir+lamivudine+lopinavir+ritona } \\
\text { vir }\end{array}$ & $1(2,3 \%)$ \\
\hline \multirow[t]{2}{*}{3} & Terapi profilaksis & \\
\hline & Kotrimoksazol & $29(67,4 \%)$ \\
\hline
\end{tabular}

Interaksi obat yang lain yaitu antara rifampisin dengan flukonazol, dimana rifampisin dapat menginduksi sitokrom P-450 khususnya tipe CYP3A4 yang mengakibatkan turunnya kosentrasi serum obat-obatan yang dimetabolisme deh isoenzim tersebut. Interaksi flukonazol dengan rifampisin dapat menurunkan kadar plasma dari flukonazol sehingga mengurangi aktivitasnya sebagai antifungi (Vadlapatla et al., 2015).

Pada prinsipnya pengobatan TB pada pasien ko-infeksi TB HIV harus diberikan segera sedangkan pengobatan ARV dimulai setelah pengobatan TB dapat ditoleransi dengan baik, dianjurkan diberikan paling cepat 2 minggu dan paling lambat 8 minggu. Pada hasil penelitian menunjukkan bahwa pasien yang mengkonsumsi OAT $<6$ bulan sebanyak 28 pasien $(65,1 \%)$ dimana konsumsi OAT 
ynag didapat adalah rifampisin, pirazinamid, etambutol dan isoniazid. Sedangkan pasien yang mengkonsumsi ART selama 1-2 tahun sebanyak 27 pasien (62,8\%). Hasil lama konsumsi OAT/ART pada pasien TB/HIV ko-infeksi dapat dilihat pada tabel 4.

\section{Tabel 4}

lama konsumsi OAT/ART pada pasien TB/HIV ko-infeksi di RSU Persahabatan Jakarta

\begin{tabular}{ccc}
\hline No & Lama konsumsi obat & Presentase \\
\hline 1 & OAT & \\
\hline \multicolumn{4}{r}{} & $<6$ bulan & $28(65,1 \%)$ \\
\hline 2 & ART & $14(32,6 \%)$ \\
\hline & $<1$ bulan & \\
\hline & $1-2$ tahun & $5(11,6 \%)$ \\
\hline & $>2$ tahun & $27(62,8 \%)$ \\
\hline
\end{tabular}

\section{Kotrimoksazol}

Merupakan kombinasi dari dua antibiotik (trimetroprim dan sulfametoksazol) yang digunakan sebagai profilaksis infeksi oportunistik yang paling umum terjadi adalah Pneumocystis carinii pneumonia (PCP) dimana sebanyak $85 \%$ pasien HIV/AIDS pada akhirnya akan mengidap PCP yang disebabkan oleh berkembangnya jamur yang ada ditubuhnya (Church, Fitzgerald, Walker, Gibb, \& Prendergast, 2015).

Penggunaan kotrimoksazol sebagai profilaksis melalui hasil penelitian sangat menguntungkan. Berdasarkan penelitian yang dilakukan di Kwazulu Natal Afrika Selatan menunjukkan penggunaan kotrimoksazol sebagai profilaksis menurunkan angka kematian TB/HIV koinfeksi sebanyak 29\% apabila pasien patuh mengkonsumsi kotrimoksazol karena efek samping kotrimoksazol tersebut tidaklah nyaman seperti sakit kepala, mual, muntah, ruam kulit, gatal hingga sindrom Stevens Johnson (Okwera, 2015).

\section{Tenovofir/Lamivudine/Evafirens}

Merupakan kombinasi obat 2 NRTI (Tenofovir + Lamivudin) dan 1 NNRTI (Evafirens) diminum pada waktu tidur di malam hari dan sebaiknya diberikan pada saat perut kosong. Pada penggunaan obat ini dapat menyebabkan interaksi obat secara farmakokinetik antara Evafirens dengan OAT terutama Rifampisin karena menginduksi CYP3A4. Tingginya penggunaan kombinasi obat ini karena evafirens merupakan pilihan utama dibandingkan dengan nevirapin dimana memiliki efek hepatotoksisitas lebih ringan dan penurunan kadar obat dalam darah akibat interaksi rifampisin lebih kecil. Perlu dilakukan monitoring ureum dan kreatinin pasien yang menggunakan kombinasi obat ini karena tenovofir memiliki efek samping toksisitas pada ginjal. Keadaan risiko 
lebih besar pada pasien $>40$ tahun, diabetes mellitus dan berat badan $<50 \mathrm{~kg}$ dan penggunaan bersama dengan Protease Inhibitor (PI) (Post et al., 2010).

\section{Lamivudin/Zidovudin/Nevirapin}

Lamivudin merupakan pilihan pertama golongan NRTI karena memiliki profil yang aman, efektif untuk terapi hepatitis B dan mudah didapat termasuk kedalam kombinasi tetap. Pilihan kedua dari golongan NRTI dalah Zidovudin karena efek samping berupa sakit kepala dan mual pada awal terapi mudah ditoleransi tetapi memerlukan pemantauan kadar Hemoglobin dalam tubuh karena dapat menimbulkan anemia berat dan neutropenia. Pilihan obat NNRTI adalah nevirapin dimana memiliki harga lebih terjangkau daripada efavirens tetapi paling banyak pasien mengalami ruam kulit mulai dari ringan hingga mengancam jiwa termasuk stevens-Johnsons, memiliki efek hepatotoksisitas lebih besar terutama pada wanita dengan jumlah CD4 >200 sel/mm3 (Vadlapatla et al., 2015), (1 Copyright 2010 by the European Respiratory Society., 2010).

\section{Hasil Laboratorium}

Pada hasil pemeriksaan laboratorium sebanyak 42 pasien yang mengkonsumsi OAT/ART menunjukkan nilai hemoglobin yang rendah $<10 \mathrm{~g} / \mathrm{dl}$ sebanyak 32 pasien $(74,4 \%)$. Hasil pemeriksaan laboratorium dapat dilihat pada tabel 5 .

Tabel 5

Hasil pemeriksaan laboratorium pada pasien TB/HIV ko-infeksi di RSU Persahabatan Jakarta

\begin{tabular}{lcll}
\hline No & Jenis laboratorium & Hasil $(\mathbf{n}=42)$ & Presentase \\
\hline $\mathbf{1}$ & Hemoglobin $(\mathrm{g} / \mathrm{dl})$ & & \\
\hline & $<10$ & 32 & $74,4 \%$ \\
\hline $\mathbf{2}$ & $10-12,5$ & 10 & $23,3 \%$ \\
\hline & CD4 $\left(\mathrm{sel} / \mathrm{mm}^{3}\right)$ & & $26,19 \%$ \\
\hline & $<200$ & 11 & $61,9 \%$ \\
\hline & $200-349$ & 26 & $11,9 \%$ \\
\hline $\mathbf{3}$ & SGOT & 5 & $38.09 \%$ \\
\hline & Meningkat 2x & 16 & $7,1 \%$ \\
\hline \multicolumn{3}{c}{ Meningkat 3x } & 3 \\
\hline & Meningkat 2x & 33 & $78,57 \%$ \\
\hline & Meningkat 3x & 9 & $21,42 \%$ \\
\hline
\end{tabular}

\section{E. Efek Samping Obat Berdasarkan Skala Naranjo}

Hasil penelitian yang diperoleh pada pasien TB/HIV ko-infeksi di RSU Persahabatan Jakarta bahwa semua pasien yang mengkonsumsi OAT/ART mengalami efek samping obat dengan probabilitas efek samping yang terjadi yaitu mungkin dan sangat mungkin. Efek samping dengan probabilitas sangat mungkin terjadi adalah ginekomastia (100\%), perubahan warna kulit $(66,7 \%)$, ruam $(65,2 \%)$, 
gangguan pendengaran, depresi $(60 \%)$ dll, yang hasil penelitian dapat dilihat pada tabel V.4.

Ginekomastia merupakan pembesaran jinak payudara pada pria yang diakibatkan proliferasi komponen kelenjar atau meningkatnya jaringan lemak pada dada. Umumnya ginekomastia terjadi bilateral, 25-30\% dapat muncul unilateral. Ginekomastia memiliki dampak negatif pada rasa percaya diri dan hubungan sosial pada pria. Penelitian yang pernah dilakukan di Malawi berdasarkan hasil penelitian efavirenz memiliki hubungan kejadian ginekomastia sehingga efavirenz diganti dengan nevirapin. Efavirenz memiliki mekanisme kerja mirip estrogen pada payudara ketika sistem imun menurun estrogen meningkat sehingga terjadilah ketidakseimbangan hormon yang menyebabkan terjadinya ginekomastia (Njuguna et al., 2016).

Pemberian kotrimokzasol sebagai standar pencegahan primer terhadap infeksi toksoplasmosis dan PCP pada pasien HIV dengan jumlah CD4< 200 sel/mm3 namun pengunaan kotrimoksazol menyebabkan efek samping obat yang tumpang tindih dengan OAT dan ART. Kejadian efek samping yang sangat mungkin terjadi di RSU Persahabatan Jakarta yaitu perubahan warna kulit $(66,7 \%)$ dan ruam kulit $(65,2 \%)$ yang disebabkan oleh pemberian kotrimoksazol dengan nevirapin hal ini dibuktikan berdasarkan studi di UK dimana pada pasein TB/HIV ko-infeksi diberi kotrimoksasol dan nevirapin dapat menyebabkan ruam kulit $(\mathrm{p}=0,001)$. (Church et al., 2015).

Efavirenz dimetabolisme oleh CYP3A4 dan CYP2B6 menjadi metabolit terhidroksilasi yang tidak aktif. Efavienz berikatan kuat dengan albumin $(99,9 \%)$ konsentrasinya dalam cairan serebrospinal $0,3-1,2 \%$ dari konsentrasinya dalam plasma. Polimorfisme gen CYP2B6 dilaporkan berhubungan dengan peningkatan konsentrasi efavirens dalam plasma menyebabkan gejala neuropskiatri. (Nightingale et al., 2015).

Tabel 6

Probabilitas kejadian efek samping yang sangat mungkin terjadi di RSU Persahabatan Jakarta yang mengkonsumsi OAT/ART

\begin{tabular}{clcccc}
\hline \multirow{2}{*}{ No } & \multirow{2}{*}{$\begin{array}{c}\text { Jenis efek } \\
\text { samping obat }\end{array}$} & \multicolumn{5}{c}{ Skala Naranjo } \\
\cline { 3 - 6 } & & \multicolumn{2}{c}{ Sangat mungkin $(+9)$} & \multicolumn{2}{c}{ Mungkin (5-8) } \\
\cline { 3 - 6 } & Sakit kepala & 13 & 56,5 & 10 & 43,5 \\
\hline 1 & $\begin{array}{l}\text { Gangguan } \\
\text { pendengaran }\end{array}$ & 9 & 60 & 6 & 40 \\
\hline 2 & Mual/muntah & 15 & 55,6 & 12 & 44,4 \\
\hline 3 & $\begin{array}{l}\text { Pengelihatan } \\
\text { kabur }\end{array}$ & 9 & 47,4 & 10 & 52,6 \\
\hline 4 & Ruam & 15 & 65,2 & 8 & 34,8 \\
\hline 5 & Perubahan & 14 & 66,7 & 7 & 33,3 \\
\hline 6 & warna kulit & & & & \\
\hline 7 & Kelelahan & 14 & 56 & 11 & 44 \\
\hline 8 & Anemia & 7 & 50 & 7 & 50 \\
\hline
\end{tabular}


Dessy Hera Setiawati, Syamsudin, Hesti Utami dan Heidy Agustin

\begin{tabular}{clcccc}
\hline 9 & $\begin{array}{l}\text { Gangguan } \\
\text { Tidur }\end{array}$ & 9 & 52,9 & 8 & 47,1 \\
\hline 10 & Depresi & 9 & 60 & 6 & 40 \\
\hline 11 & Neuropati & 14 & 46,7 & 16 & 53,3 \\
\hline 11 & Ginekomastia & 1 & 100 & 0 & 0 \\
\hline 12 & Diare & 8 & 44,4 & 10 & 55,6 \\
\hline
\end{tabular}

Ototoksisitas yang timbul disebabkan oleh golongan aminoglikosida yaitu streptomisin. Mekanisme kerja golongan antibiotik ini yaitu berikatan langsung dengan RNA $16 \mathrm{~S}$ pada subunit $30 \mathrm{~S}$ pada ribosom bakteri yang menyebabkan mistranslasi pada sintesis protein. Ototoksisitas berkaitan dengan mutasi genetik $12 \mathrm{~S}$ r-RNA, dimana subunit $12 \mathrm{~S}$ r-RNA berikatan pada mitokondria bakteri dan yeast yang menyebabkan resisten pada aminoglikosida (Adeyemo, Oluwatosin, \& Omotade, 2016).

\section{E. Hasil Analisis Bivariat}

Pada analisis ini hanya digunakan untuk mengetahui ada atau tidaknya hubungan dua variabel. Dimana peneliti ingin mengetahui hubungan antara faktor resiko yang ada dengan kejadian efek samping obat yang terjadi yang di ukur berdasarkan skala Naranjo. Sebanyak 42 responden dengan kriteria inklusi yang diharapkan semua pasien mengalami kejadian efek samping obat dengan probabilitas kejadian efek samping yang mungkin terjadi dan sangat mungkin terjadi yang mana hasilnya dapat dilihat pada tabel V.5.

\section{Jenis kelamin}

Dari 42 sampel yang diambil didapat 27 orang $(62,8 \%)$ berjenis kelamin pria dan 15 orang $(34,9 \%)$ berjenis kelamin wanita. Dari hasil analisa diperoleh bahwa variabel jenis kelamin tidak berkontribusi bermakna secara statistik terhadap terjadinya efek samping obat yang terjadi di RSU Persahabatan Jakarta $(\mathrm{P}=0,231)$. Penelitian lain yang dilakukan di RSUP.Dr.Kariadi Semarang juga menunjukkan bahwa jenis kelamin tidak berkontribusi bermakna secara statistik ( $\mathrm{P}=0,735)$ (Natalie et al., 2016).

Dalam penelitian ini jenis kelamin pria bukan merupakan faktor resiko terjadinya efek samping obat pada pasien TB/HIV ko-infeksi. Hal ini berbeda dari penelitian sebelumnya yang dilakukan di Brazil menyatakan bahwa pasien dengan jenis kelamin pria merupakan faktor resiko terjadinya efek samping obat pada pasien TB/HIV ko-infeksi (Teixeira et al., 2018). 


\section{Tabel 7}

Analisis variabel yang kemungkinan berkontribusi terhadap kejadian efek samping obat berdasarkan skala Naranjo pada pasien TB/HIV ko-infeksi

\begin{tabular}{|c|c|c|c|c|c|c|c|}
\hline \multirow[b]{2}{*}{ No } & \multirow[b]{2}{*}{ Variabel } & \multicolumn{4}{|c|}{ Skala naranjo } & \multirow{2}{*}{$\begin{array}{l}\mathrm{P} \\
\text { value }\end{array}$} & \multirow{2}{*}{ OR } \\
\hline & & $\begin{array}{l}\text { Sangat } \\
(+9)\end{array}$ & mungkin & \multicolumn{2}{|c|}{ Mungkin (5-8) } & & \\
\hline \multicolumn{8}{|c|}{ 1.Faktor demografi } \\
\hline & Usia & $\mathrm{n}$ & $\%$ & $\mathrm{n}$ & $\%$ & 0,085 & 4,286 \\
\hline & 18-30 tahun & 6 & 75 & 2 & 25 & & \\
\hline & $31-60$ tahun & 14 & 41,2 & 20 & 58,8 & & \\
\hline & Jenis kelamin & & & & & 0,231 & 0,458 \\
\hline & Pria & 11 & 40,4 & 16 & 59,3 & & \\
\hline & Wanita & 9 & 60 & 6 & 40 & & \\
\hline \multirow[t]{3}{*}{$\mathrm{C}$} & BMI & & & & & & \\
\hline & Underweight $\left(<18,5 \mathrm{~kg} / \mathrm{m}^{2}\right)$ & 14 & 56 & 11 & 44 & 0,187 & 2,333 \\
\hline & $\begin{array}{l}\text { Tidak Underweight } \\
\left(18,6-25,71 \mathrm{~kg} / \mathrm{m}^{2}\right)\end{array}$ & 6 & 35,3 & 11 & 64,7 & & \\
\hline \multicolumn{8}{|c|}{ 2.Faktor sosial } \\
\hline \multicolumn{8}{|c|}{ A Merokok } \\
\hline & $\mathrm{Ya}$ & 11 & 37,9 & 18 & 62,1 & 0,616 & 0,713 \\
\hline & Tidak & 6 & 46,2 & 7 & 53,8 & & \\
\hline \multirow[t]{3}{*}{$\mathrm{B}$} & Konsumsi alkohol & & & & & & \\
\hline & $\mathrm{Ya}$ & 11 & 50 & 11 & 50 & 0,187 & 2,333 \\
\hline & Tidak & 6 & 30 & 14 & 70 & & \\
\hline \multicolumn{8}{|c|}{ 3.Faktor obat } \\
\hline \multicolumn{8}{|c|}{$\begin{array}{ll}\text { A } & \text { Konsumsi obat lain } \\
\end{array}$} \\
\hline & $\mathrm{Ya}$ & 14 & 60,9 & 9 & 39,1 & 0,059 & 3,370 \\
\hline & Tidak & 6 & 31,6 & 13 & 68,4 & & \\
\hline \multirow[t]{3}{*}{$\mathrm{B}$} & Terapi Kotrimoksazol & & & & & & \\
\hline & $\mathrm{Ya}$ & 13 & 44,8 & 16 & 55,2 & 0,391 & 1,828 \\
\hline & Tidak & 4 & 30,8 & 9 & 69,2 & & \\
\hline & Lama terapi OAT & & & & & & \\
\hline & $<6$ bulan & 9 & 32,1 & 19 & 67,9 & 0,005 & 3,370 \\
\hline & $6-8$ bulan & 11 & 78,6 & 3 & 21,4 & & \\
\hline & Putus obat & & & & & & \\
\hline & $\mathrm{Ya}$ & 13 & 43,3 & 17 & 56,7 & 0,551 & 1,529 \\
\hline & Tidak & 4 & 33,3 & 8 & 66,7 & & \\
\hline \multicolumn{8}{|c|}{ 4.Faktor penyakit } \\
\hline \multicolumn{8}{|c|}{ A $\quad$ Komplikasi penyakit lain } \\
\hline & $\mathrm{Ya}$ & 12 & 48 & 13 & 52 & 0,228 & 2,215 \\
\hline & Tidak & 5 & 39,4 & 12 & 70,6 & & \\
\hline \multirow[t]{4}{*}{ B } & Stadium HIV & & & & & & \\
\hline & Asimptomatis & 1 & 50 & 1 & 50 & 0,927 & \\
\hline & Mild & 5 & 41,7 & 7 & 58,3 & & \\
\hline & Moderat & 8 & 36,4 & 14 & 63,6 & & \\
\hline \multicolumn{8}{|c|}{ Hasil laboratorium } \\
\hline & BTA & & & & & & \\
\hline & Positif & 7 & 38,9 & 11 & 61,1 & 0,856 & 0,891 \\
\hline & Negatif & 10 & 41,7 & 14 & 58,3 & & \\
\hline & $\mathrm{Hb}(\mathrm{g} / \mathrm{dl})$ & & & & & & \\
\hline & $<10$ & 13 & 43,8 & 19 & 56,3 & 0,439 & 1,815 \\
\hline
\end{tabular}


Dessy Hera Setiawati, Syamsudin, Hesti Utami dan Heidy Agustin

\begin{tabular}{|c|c|c|c|c|c|c|c|}
\hline \multirow[b]{2}{*}{ No } & \multirow[b]{2}{*}{ Variabel } & \multicolumn{4}{|c|}{ Skala naranjo } & \multirow{2}{*}{$\begin{array}{l}\mathrm{P} \\
\text { value }\end{array}$} & \multirow{2}{*}{ OR } \\
\hline & & $\begin{array}{l}\text { Sangat } \\
(+9)\end{array}$ & mungkin & \multicolumn{2}{|c|}{ Mungkin (5-8) } & & \\
\hline & $10-12,5$ & 3 & 30 & 7 & 70 & & \\
\hline \multirow[t]{4}{*}{$\mathrm{D}$} & CD4 $\left(\mathrm{sel} / \mathrm{mm}^{3}\right)$ & & & & & & \\
\hline & $<200$ & 8 & 72,7 & 3 & 27,3 & 0,020 & \\
\hline & $200-349$ & 8 & 30,8 & 18 & 69,2 & & \\
\hline & $350-500$ & 4 & 80 & 1 & 20 & & \\
\hline \multirow[t]{4}{*}{$\mathrm{E}$} & SGOT & & & & & & \\
\hline & Normal & 11 & 47,8 & 12 & 52,2 & 0,868 & \\
\hline & Meningkat 2x & 8 & 50 & 8 & 50 & & \\
\hline & Meningkat 3x & 1 & 33,3 & 2 & 66,7 & & \\
\hline \multirow[t]{3}{*}{$\mathrm{F}$} & SGPT & & & & & & \\
\hline & Meningkat 2x & 16 & 48,5 & 17 & 51,5 & 0,850 & 1,176 \\
\hline & Meningkat 3x & 4 & 44,4 & 5 & 55,6 & & \\
\hline
\end{tabular}

\section{Usia}

Dari 42 pasien sebagai responden didapatkan kelompok usia 18-30 tahun sebanyak 8 orang $(18,6 \%)$ dan kelompok usia 31-60 tahun sebanyak 34 orang $(79,1 \%)$. Pada penelitian ini didapat bahwa variabel usia tidak bermakna secara statistik terhadap kejadian efek samping obat yang terjadi $(\mathrm{P}=0,085)$. Dari hasil analisis diperoleh pula nilai $(\mathrm{OR}=4,286)$ artinya bahwa kelompok usia 31-60 tahun memiliki resiko 4,286 kali terhadap kejadian efek samping obat yang terjadi dibandingkan dengan kelompok usia 18-30 tahun. Variabel usia memiliki kecendrungan berhubungan tetapi tidak bermakna secara statistik dimana hal ini kemungkinan dapat disebabkan karena distribusi sampel yang tidak homogen.

Penelitian di RSUP.Dr.Kariadi Semarang memiliki hasil yang sama dimana usia tidak bermakna secara statistik terhadap kejadian efek samping obat yang terjadi, Akan tetapi penelitian lain yang dilakukan di Nigeria memiliki hubungan signifikan secara statistik antara usia dengan kejadian efek samping obat yang terjadi $(\mathrm{P}=0,025)$ dengan rentang usia produktif $>35$ tahun (Natalie et al., 2016),(No Title, 2012).

\section{BMI}

Hasil analisis menunjukkan bahwa BMI pada pasien TB/HIV ko-infeksi di Rumah Sakit Umum Persahabatan Jakarta menunjukkan bahwa sebanyak 25 pasien $(59,5 \%)$ dalam BMI underweight $(18,5 \mathrm{~kg} / \mathrm{m} 2)$ dan 17 pasien $(40,5 \%)$ dengan BMI tidak underweight $(18,6-25,71 \mathrm{~kg} / \mathrm{m} 2)$ tidak menunjukkan hubungan secara statistik $(\mathrm{P}=0,187)$ akan tetapi memperoleh nilai $(\mathrm{OR}=2,333)$ artinya bahwa pasien denga BMI underweight memiliki resiko 2,333 kali mengalami kejadian efek samping obat daripada pasien dengan BMI tidak underweight.

Malnutrisi pada pasien TB/HIV ko-infeksi terkait dengan gejala klinis pasien tersebut seperti diare, penurunan berat badan yang drastis akibat gangguan metabolik lainnya. Dalam penelitian di RS. Dr. Moewardi 
menyebutkan bahwa pasien dengan nilai IBM $<18 \mathrm{~kg} / \mathrm{m} 2$ memiliki prognosis lebih berat 1,5 kalinya dan tingkat kematian lebih tinggi 1,9 kalinya dibandingkan dengan subjek berat badan normal. Malnutrisi pada pasien TB/HIV ko-infeksi dapat menyebabkan penurunan limfosit dan proliferasi sel imun yang dapat mengakibatkan meningkatnya pertumbuhan mikroorganisme (Infeksi et al., 2015),(Pengembsngfln, Keprotesiun, \& Tuberkulosis, 2012).

\section{Hemoglobin}

Pada penelitian ini hasil analisis menunjukkan bahwa pasien dengan kadar HB < 10 g/dl sebanyak 32 pasien $(74,4 \%)$ dan pasien dengan kadar HB $10-12,49 \mathrm{~g} / \mathrm{dl}$ sebanyak 10 pasien $(23,8 \%)$ dari hasil analisis tidak menunjukkan kontribusi bermakna secara statistik terhadap efek samping obat yang terjadi $(\mathrm{P}=0,439)$. Dari uji statistik juga diperoleh nilai $(\mathrm{OR}=1,815)$ dimana pada kelompok HB $<10 \mathrm{~g} / \mathrm{dl}$ memiliki resiko 1,815 kali terhadap efef samping obat yang terjadi dibandingkan dengan kelompok HB 10-12,49 g/dl. Pada penelitian di Brazil membuktikan dengan hasil yang sama yaitu tidak memiliki hubungan bermakna secara statistik $(\mathrm{P}=1,00)$ (Teixeira et al., 2018).

Hasil ini berbeda dari penelitian sebelumnya yang menunjukkan adanya hubungan secara statistik antara kejadian efek samping obat terhadap pasien TB/HIV ko-infeksi di RSUP Dr.Kariadi Semarang ( $\mathrm{P}=0,001)$ dan penelitian lain di Ethiopia menunjukkan bahwa kadar hemoglobin bermakna secara statistik terhadap terjadinya TB/HIV ko-infeksi karena anemia dikaitkan dengan malnutrisi yang memperberat kondisi pasien yang dapat memperberat kondisi imun (Church et al., 2015).

\section{Jumlah CD 4}

Sebanyak 42 pasien TB/HIV ko-infeksi yang mendapatkan terapi ART/OAT 11 orang dengan jumlah CD4 < 200 sebanyak 26 pasien dengan jumlah CD4 200-349 dan pasien dengan jumlah CD4 350-499 sebanyak 5 orang. Berdasarkan analisa statistik berhubungan signifikan secara statistik dengan jumlah CD4 $(\mathrm{P}=0,020)$. Penelitian yang dilakukan oleh Lies dkk menunjukkan hal yang berbeda dimana tidak ada hubungan signifikan secara statistik antara jumlah CD4 dengan kejadian efek samping obat $(\mathrm{P}=0,444)$ dengan jumlah CD4 $<100 \mathrm{sel} / \mathrm{mm} 3$ begitupula penelitian yang dilakukan di RSU. Dr. Kariadi Semarang sebanyak 55 (87,30\%) pasien CD4 <100 sel/mm3dengan TB/HIV ko-infeksi menunjukkan tidak ada hubungan signifikan dengan kejadian efek samping obat $(\mathrm{P}=0,442)$. Hal ini berbeda dengan beberapa penelitian sebelumnya dilakukan oleh Dean et al dimana jumlah CD4 berhubungan signifikan dengan kejadian efek samping obat yang terjadi pada 3 bulan pertama menggunakan OAT/ART $(\mathrm{P}=0,036)$ dan selama 9 bulan menggunakan OAT/ART ( $\mathrm{P}=0,001)$ (Natalie et al., 2016),(Dean et al., 2002). 


\section{Merokok}

Pada 42 pasien sebanyak 29 (69\%) pasien memiliki riwayat merokok dan 13 pasien lainnya tidak merokok. Berdasarkan hasil analisa di dapat bahwa riwayat merokok tidak memiliki hubungan yang signifikan secara statistik terhadap kejadian efek samping obat yang terjadi $(\mathrm{P}=0,616)$. Pada penelitian sebelumnya yang dilakukan di RS. Kariadi Semarang juga tidak ditemukan hubungan yang signifikan secara statistik $(\mathrm{P}=0,598)$. Hal ini dapat terjadi karena jumlah pasien sedikit dan catatan rekam medik yang kurang lengkap (Natalie et al., 2016).

\section{Konsumsi alkohol}

Sebanyak $22(51,2 \%)$ responden dari 42 sampel di Rumah Sakit Umum Persahabatan Jakarta memiliki riwayat konsumsi alkohol dimana berdasarkan hasil analisis tidak ditemukan hubungan yang signifikan secara statistik $(\mathrm{P}=0,746)$ kemungkinan karena jumlah sampel yang sedikit. Dari hasil analisis diperoleh pula nilai $(\mathrm{OR}=2,333)$, artinya responden yang memiliki riwayat konsumsi alkohol memiliki resiko 2,333 kali terhadap efek samping obat yang terjadi dibandingkan dengan responden yang tidak memiliki riwayat konsumsi alkohol. Pada penelitian ini peneliti tidak menghitung banyaknya yang diminum, dinilai berdasarkan frekuensi minum dan didapatkan pasien minum alkohol seminggu dua kali sebanyak 12 orang, minum alkohol setiap hari 4 orang, minum sebulan sekali 6 orang. Hasil tersebut dapat dilihat pada tabel 8 . Alkohol menimbulkan efek toksik bagi peminumnya dimana akan terjadi defisiensi mikronutrien dan makronutrien sehingga menurunnya sistem imun, menurunnya limfosit $\mathrm{B}$ dan limfosit $\mathrm{T}$, terjadi ganguan fungsi makrofag, dan inhibisi dari TNF, NO, IL-2, dan proliferasi CD4 yang menyebabkan destruksi M.tuberculosis terhambat (Silva et al., 2018).

Tabel 8

Frekuensi konsumsi alkohol

\begin{tabular}{llcl}
\hline No & Frekuensi konsumsi alkohol & Jumlah $(\mathrm{n}=42)$ & Presentase \\
\hline 1 & Dua kali seminggu & 13 orang & $31 \%$ \\
\hline 2 & Setiap hari & 4 orang & $9,5 \%$ \\
\hline 3 & Sebulan sekali & 6 orang & $14,3 \%$ \\
\hline 4 & Tidak konsumsi alkohol & 19 orang & $45,2 \%$ \\
\hline
\end{tabular}

\section{Lama terapi OAT}

Berdasarkan hasil analisis lama terapi OAT fase awal sebanyak 28 orang mengkonsumsi OAT fase awal $(65,1 \%)$ dan 14 orang mengkonsumsi OAT fase lanjutan 32,6\%. Berdasarkan analisis menunjukkan bahwa pada ada hubungan antara lama terapi OAT dengan kejadian efek samping obat yang terjadi $(\mathrm{P}=0,005)$. Sehingga diduga efek samping yang timbul disebabkan oleh kombinasi OAT yang terdiri dari Rifampisin, Pirazinamid, Etambutol dan Isoniazid pada fase awal atau fase intensif. Dari hasil analisis juga diperoleh nilai $(\mathrm{OR}=3,370)$, artinya kelompok pasien yang mengkonsumsi OAT pada fase awal memiliki resiko 3,370 kali terjadinya efek samping obat 
dibandingkan dengan kelompok pasien yang mengkonsumsi OAT pada fase lanjutan. Banyaknya obat yang dikonsumsi dapat meningkatkan terjadinya interaksi obat. Hasil ini sama dari penelitian sebelumnya yang dilakukan di RSUP DR.Kariadi Semarang bahwa lama terapi OAT bermakna secara statistik ( $\mathrm{p}=0,001)$ pada kejadian efek samping obat yang terjadi dan memiliki peluang 1,471 kali terhadap kejadian efek samping obat. Penelitian lain yang dilakukan di Nigeria menunjukkan ada hubungan signifikan secara statistik $(\mathrm{P}=0,003)$ pada kejadian efek samping obat terhadap lama terapi OAT (Natalie et al., 2016),(Teixeira et al., 2018).

9. BTA

Diantara 42 total pasien yang memenuhi kriteria inklusi menunjukkan pemeriksaan BTA negatif sebanyak 24 pasien (55,8\%) tidak memiliki hubungan secara statistik terhadap probabilitas efek samping obat yang terjadi $(\mathrm{P}=0,856)$ dari hasil tersebut diperoleh nilai $(\mathrm{OR}=0,891)$ dimana pasien dengan nilai BTA negatif memiliki resiko sebesar 0,891 kali terhadap kejadian efek samping obat yang terjadi.

Beberapa kepustakaan menunjukkan bahwa menurunnya derajat imunosupresi akan mempengaruhi gambaran bakteriologis pasien TB/HIV koinfeksi sehingga sering memberikan hasil sputum BTA negatif. Pada penelitian sebelumnya yang dilakukan di RS.Dr. Moewardi mendapatkan hasil perolehan BTA negatif (73\%) pada pasien TB/HIV ko-infeksi lebih besar daripada pasien dengan BTA positif hanya 4 pasien $(11,4 \%)$ Sedangkan penelitian yang dilakukan di RSUD Buleleng menunjukkan bahwa pemerikasaan dengan BTA negatif lebih besar $(32,51 \%)$. Penyebab pasien dengan BTA negatif berhubungan dengan mortalitias tinggi akibat imunosupresi yang berat sehingga tanda dan gejala klinis TB menjadi tidak spesifik sehingga diagnosis pada TB sering tertunda (Agustya et al., n.d.),(Infeksi et al., 2015).

\section{Nilai SGOT/SGPT}

Dari pemeriksaan fungsi hati yang dilakukan diperoleh nilai SGOT pada pasien TB/HIV ko-infeksi di RSU Persahabatan Jakarta terendah adalah 21 IU/L dan nilai tertinggi $104 \mathrm{IU} / \mathrm{L}$ dengan rata-rata 43,52 IU/L dari hasil estimasi interval $95 \%$ di dapatkan rata-rata nilai SGOT diantara 37,35 $\pm 49,69$ IU/L. Hasil nilai SGPT terendah diperoleh nilai 19 IU/L dan tertinggi 83 UI/L dengan rata-rata 41,89 UI/L dari hasil estimasi interval 95\% diperoleh hasil; $35,83 \pm 48,12$ UI/L. Hasil yang diperoleh dari bivariat terhadap kejadian efek samping obat yang terjadi menunjukkan tidak bermakna secara statistik untuk nilai SGOT $(\mathrm{P}=0,868)$ dan nilai SGPT $(\mathrm{P}=0,850)$. Dari hasil statistik diperoleh hasil untuk nilai SGPT yaitu $(\mathrm{OR}=1,170)$ dimana resiko kejadian efek samping obat 1,170 kali pada nilai SGPT yang meningkat dua kalinya daripada nilai SGPT dibandingkan dengan nilai SGOT yang meningkat hingga tiga kali. Nilai SGPT/SGOT meningkat 2-3 kalinya yang mengindikasikan bahwa ada kejadian hepatotoksisitas imbas obat pada pasien TB/HIV ko-infeksi. 
Penelitian ini serupa yang dilakukan oleh Lies di RSCM menunjukkan bahwa terjadi peningkatan SGPT di awal yang meningkat secara bermakna secara statistik $(\mathrm{P}=0,002$; $\mathrm{OR}=7,5$; $\mathrm{CI} 95 \%$ 1,72-32,80) dimana peningkatan nilai SGOT/SGPT beasal dari konsumsi obat lain dan Penelitian lain yang dilakukan oleh Made di RSUD Buleleng menunjukkan terdapat peningkatan enzim hati SGOT/SGPT. Kadar SGPT pasien koinfeksi TB-HIV didapatkan nilai terendah $8 \mathrm{IU} / \mathrm{L}$ dan nilai tertinggi $171 \mathrm{IU} / \mathrm{L}$ dengan rerata 43,63 $\pm 44,432$ IU/L. Peningkatan kadar SGPT didapatkan pada 9 pasien $(25,7 \%)$. Kadar SGOT pasien koinfeksi TB-HIV didapatkan nilai terendah 17 IU/L dan nilai tertinggi $143 \mathrm{IU} / \mathrm{L}$ dengan rerata 56,51 \pm 36,207 IU/L. Mayoritas pasien mengalami peningkatan kadar SGOT yaitu sebanyak 20 pasien $(57,1 \%)$ (Penelitian, n.d.),(Infeksi et al., 2015).

\section{Konsumsi obat lain}

Berdasarkan hasil analisis dari 42 sampel penelitian pada pasien TB/HIV ko-infeksi yang mengkonsumsi obat selain OAT/ART menunjukkan sebanyak 23 pasien $(53,5 \%)$. Tetapi tidak bermakna secara statistik $(\mathrm{P}=0,059)$. Obat yang dikonsumsi dapat dilihat pada tabel 9.

\section{Tabel 9}

Obat lain yang dikonsumsi selain OAT/ART

\begin{tabular}{clc}
\hline No & Nama obat & Jumlah pasien \\
\hline 1 & Flukonazole & 7 \\
2 & Candistin drop & 12 \\
3 & Amlodipin & 3 \\
4 & Simvastatin & 5 \\
5 & Metformin & 2 \\
6 & Siproflokasasin & 1 \\
7 & Risperidone & 3 \\
8 & Jamu dan Vitamin & 11 \\
\hline
\end{tabular}

Banyaknya pasien TB/HIV ko-infeksi mengalami infeksi oportunistik dan resiko terbesar apabila jumlah CD4 $<200 \mathrm{sel} / \mathrm{mm} 3$. Kandidiasis mukosa paling sering terjadi pada pasien HIV yang disebabkan oleh Candida albican. Golongan azole sebagai antijamur merupakan pengobatan jamur topical dan sistemik. Flukonazole merupakan agent potensial inhibitor pada CYP2C9 dan inhibitor moderat pada CYP3A4 seperti golongan obat Lopinavir/ritronavir. Aktivitas nystatin utama adalah melawan Candida sp yang mekanisme kerjanya adalah mengadakan ikatan yang kompleks dengan ergosterol di membran sitoplasma jamur sehingga mengalami perubahan permeabilitas membran dengan membentuk pori-pori intra membran sehingga intra sel kehilangan senyawa penting yang menyebabkan kematian sel. Efek samping yang paling banyak ditemui adalah mual, muntah, diare apabila nystatin diberikan secara oral (Vadlapatla et al., 2015). 


\section{Komplikasi penyakit lain}

Infeksi oportunistik merupakan mikosis dengan insiden tinggi pada infeksi oportunistik. Hal tersebut dikarenakan jamur merupakan flora normal yang beradaptasi pada inang manusia terutama pada saluran cerna, urogenital dan kulit. Pada penelitian yang pernah dilakukan menunjukkan penderita kandidiasis merupakan infeksi oportunistik yang paling banyak yang dialami pada pasien TB/HIV ko-infeksi di RSUP Sanglah Denpasar 43,9 \% dengan 18 kasus yang terjadi (Human \& Virus, 2011).

Diabetes Melitus pada pasien TB/HIV ko-infeksi disebabkan kondisi hiperglikemi pada penderita diabetes tipe 2 sehingga dapat menyebabkan penurunan berat badan yang drastis dan dapat memicu terjadinya kurang gizi. Hal ini dapat disebabkan oleh penurunan fungsi dari makrofag dan limfosit yang menyebabkan imunitas menurun sehingga mudah terserang infeksi. Penelitian yang dilakukan oleh Dinkes Kota Surabaya melaporkan bahwa kejadian Diabetes mellitus tipe 2 merupakan faktor resiko terjadinya TB/HIV ( $\mathrm{p}=0,022$ ) (Epidemiologi, Timur, \& Melitus, 2017).

Hasil dari analisis terhadap variabel diatas membuktikan bahwa variabel yang berkontribusi terhadap kejadian efek samping obat dengan nilai signifikansi $<0,05$ adalah lama terapi OAT $(\mathrm{P}=0,005)$ dengan nilai $(\mathrm{OR}=3,370)$. Sedangkan variabel yang lain tidak berhubungan signifikan secara statistik dapat dimasukkan kedalam analisis multivariat dengan nilai signifikasi <0,25.

\section{F. Hasil Analisis Multivariat}

Dari hasil bivariat variabel yang diduga memiliki hubungan dengan nilai signifikasi $<0,25$ dilanjutkan dengan analisis multivariat variabel itu adalah umur $(\mathrm{P}=0,085)$, jumlah $\mathrm{CD} 4(\mathrm{P}=0,020)$, lama terapi OAT $(\mathrm{P}=0,005)$ dan konsumsi obat lain $(\mathrm{P}=0,059)$ dan diperoleh hasil multivariat yang dapat dilihat pada tabel 10 .

\section{Tabel 10}

\section{Hasil analisis multivariat}

\begin{tabular}{clccc}
\hline No & \multicolumn{1}{c}{ Variabel } & P value & OR & $95 \%$ CI \\
\hline 1 & Umur & 0,010 & 47,289 & $2,520-887,390$ \\
2 & Konsumsi obat lain & 0,010 & 15,367 & $1,934-122,114$ \\
\hline
\end{tabular}

Dari tabel diatas menunjukkan bahwa pasien dengan usia > 31-60 tahun secara signifikan berhubungan dengan kejadian efek samping obat yang sangat mungkin terjadi berdasarkan skala Naranjo $(\mathrm{P}=0,010)$ dan memiliki risiko 47,289 kali (95\% CI: 2,520-887,390). Artinya ada hubungan pasien dengan usia >31-60 tahun mempunyai risiko terjadinya efek samping obat sangat mungkin terjadi 47,289 kali lebih besar dibandingkan dengan pasien usia 18-30 tahun. Pasien TB/HIV ko-infeksi yang mengkonsumsi obat lain secara signifikan berhubungan dengan efek samping obat yang sangat mungkin terjadi berdasarkan skala Naranjo $(\mathrm{P}=0,010)$ dan memiliki resiko 15,367 kali $(95 \% \mathrm{CI}$ : 
Dessy Hera Setiawati, Syamsudin, Hesti Utami dan Heidy Agustin

1,934-122,114). Dimana ada hubungan antara pasien yang mengkonsumsi obat lain selain OAT/ART terhadap efek samping obat yang sangat mungkin terjadi. dengan risiko 15,367 kali dibandingakan dengan pasien yang tidak mengkonsumsi obat lain selain OAT/ART.

\section{Kesimpulan}

Sebanyak 42 responden TB/HIV ko-infeksi yang mengkonsumsi OAT/ART semua pasien mengalami kejadian efek samping obat dengan probabilitas sangat mungkin dan mungkin. Kejadian efek samping obat yang paling banyak dialami adalah neuropati perifer, mual/muntah, ruam, kelelahan, sakit kepala. Probabilitas efek samping yang sangat mungkin terjadi berdasarkan skala Naranjo adalah ginekomastia, perubahan warna kulit, ruam, gangguan pendengaran dan depresi. Variabel secara signifikan berhubungan dengan efek samping obat pada pasien TB/HIV ko-infeksi dengan probabilitas sangat mungkin adalah usia >31-60 tahun dengan risiko 47,289 kalinya dibandingkan dengan usia 18-30 tahun dan konsumsi obat selain OAT/ART dengan risiko 15,367 kali. 


\section{BIBLIOGRAFI}

Adeyemo, Adebolajo A., Oluwatosin, Odunayo, \& Omotade, Olayemi O. (2016). Study of Streptomycin-Induced Ototoxicity: Protocol For A Longitudinal Study. SpringerPlus.

Agustya, Made, Putra, Darma, \& Putra, I. Nyoman Nama. (n.d.). Profil Pasien Koinfeksi TB - HIV. Indonesian Jurnal Applied Science. 36(3), 175-181.

Bruchfeld, Judith, Correia-Neves, Margarida, \& Källenius, Gunilla. (2015). Tuberculosis and HIV coinfection. Cold Spring Harbor Perspectives in Medicine, 5(7), a017871.

Church, James A., Fitzgerald, Felicity, Walker, A. Sarah, Gibb, Diana M., \& Prendergast, Andrew J. (2015). The Expanding Role of Co-Trimoxazole In Developing Countries. The Lancet Infectious Diseases, 15(3), 327-339. https://doi.org/10.1016/S1473-3099(14)71011-4

Dean, Gillian L., Edwards, Simon G., Ives, Natalie J., Matthews, Gail, Fox, Emma F., Navaratne, Lesley, Fisher, Martin, Taylor, Graham P., Miller, Rob, Taylor, Chris B., Ruiter, Annemiek De, \& Pozniak, Anton L. (2002). Treatment of tuberculosis in HIV-infected persons in the era of highly active antiretroviral therapy.

Eluwa, George I., Badru, Titilope, \& Akpoigbe, Kesiena J. (2012). Adverse drug reactions to antiretroviral therapy (ARVs): incidence, type and risk factors in Nigeria. BMC Clinical Pharmacology, 12(1), 7.

Epidemiologi, Departemen, Timur, Jawa, \& Melitus, Diabetes. (2017). Hubungan Sosioekonomi Dan Gizi Dengan Risiko Tuberkulosis Pada Penderita Dm Tipe 2. (July), 185-194. https://doi.org/10.20473/jbe.v5i2.2017.185-194

Getahun, Haileyesus, Gunneberg, Christian, Granich, Reuben, \& Nunn, Paul. (2008). HIV Infection - Associated Tuberculosis: The Epidemiology and the Response. 50, 201-207. https://doi.org/10.1086/651492

Getahun, Haileyesus, Gunneberg, Christian, Granich, Reuben, \& Nunn, Paul. (2010). HIV infection-associated tuberculosis: the epidemiology and the response. Clinical Infectious Diseases, 50(Supplement_3), S201-S207.

Human, Epidemi, \& Virus, Immunodeficiency. (2011). Studi Penggunaan Obat Anti Tuberkulosis Pada Pasien Tb-Hiv / Aids Di Rsup Sanglah Denpasar Tahun 2009. 14(02).

Infeksi, Penyakit, Prof, Rspi, Saroso, Sulianti, Suspected, Profile, Patients, Tb hiv, Disease, Infectious, Prof, Hospital, Murtiani, Farida, Setianingsih, Tri Yuli, Permatasari, Debby, Sakit, Rumah, Infeksi, Penyakit, Prof, Rspi, \& Saroso, Sulianti. (2015). Profil Pasien Suspek Koinfeksi TB pada HIV di Rumah Sakit. 1421. 
Dessy Hera Setiawati, Syamsudin, Hesti Utami dan Heidy Agustin

Irawati, Elfride, Biologi, Fakultas, \& Papua, Universitas Cenderawasih. (2017). Profil Pasien Ko-Infeksi Tuberculose-Hiv Tuberculosis-HIV Co-infection Profile in DOK II Hospital Jayapura. 7, 25-28.

Mafukidze, Arnold T., Calnan, Marianne, \& Furin, Jennifer. (2016). Journal of Clinical Tuberculosis and Other Mycobacterial Diseases Peripheral neuropathy in persons with tuberculosis. Journal of Clinical Tuberculosis and Other Mycobacterial Diseases, 2, 5-11. https://doi.org/10.1016/j.jctube.2015.11.002

Michael, O. S., Sogaolu, O. M., Fehintola, F. A., Ige, O. M., \& Falade, C. O. (2016). Adverse Events To First Line Anti-Tuberculosis Drugs In Patients Co-Infected With Hiv And Tuberculosis. 14(1), 21-29.

Natalie, Josephine, Kholis, Fathur Nur, \& Ngestiningsih, Dwi. (2016). Jenis- Jenis Efek Samping Pengobatan Oat Dan Art Pada Pasien Dengan Koinfeksi Tb / Hiv Di Rsup Dr . Kariadi. 5(4), 1134-1145.

Nightingale, Sam, Winsto, Alan, Letendre, Scott, Michael, Benedict D., Mcarthur, Justin C., Khoo, Saye, \& Solomon, Tom. (2015). Controversies in HIV-associated neurocognitive disorders. 13(11), 1139-1151. https://doi.org/10.1016/S14744422(14)70137-1.Controversies

Njuguna, Christine, Swart, Annoesjka, Blockman, Marc, Maartens, Gary, Chisholm, Briony, \& Stewart, Annemie. (2016). Cases of antiretroviral - associated gynaecomastia reported to the National HIV \& Tuberculosis Health Care Worker Hotline in South Africa. AIDS Research and Therapy, 1-5. https://doi.org/10.1186/s12981-016-0121-z

Olowe, Olugbenga A., Makanjuola, Olufunmilola B., Adekanmi, Adeniyi S., \& Adefioye, Olusola J. (2017). Original article Epidemiological Characteristics And Clinical Outcome Of Hiv-Related Tuberculosis In A Population Of Tb Patients In South-Western Nigeria. 7, 127-132. https://doi.org/10.1556/1886.2017.00003

Pacific, Asia. (2014). Asia Pacific allergy.

Penelitian, Laporan. (n.d.). Risk Factors of Antituberculosis Induced-Hepatotoxicity among HIV / AIDS Patients Faktor Risiko Terjadinya Hepatotoksisitas Imbas Obat Antituberkulosis pada Pasien HIV / AIDS. 4(1), 23-28.

Pengembsngfln, Artiket, Keprotesiun, Pendidikan, \& Tuberkulosis, Malnutrisi. (2012). No Title.

Post, Frank A., Sa, F. C. P., Moyle, Graeme J., Ju, Hans, Domingo, Pere, Podzamczer, Daniel, Fisher, Martin, Norden, Anthony G., Cavassini, Matthias, Rieger, Armin, Branco, Teresa, Pearce, Helen C., Givens, Naomi, Vavro, Cindy, \& Lim, Michael L. (2010). Randomized Comparison of Renal Effects, Efficacy, and Safety With Once-Daily Abacavir / Lamivudine Versus Tenofovir / Emtricitabine, Administered 
With Efavirenz, in Antiretroviral-Naive, HIV-1 - Infected Adults: 48-Week Results From the ASSERT Study. 55(1), 49-57.

Robinson-papp, Jessica. (2013). HIV-related neuropathy: current perspectives. 243-251. Silva, Denise Rossato, Muñoz-torrico, Marcela, Duarte, Raquel, Galvão, Tatiana, Bonini, Eduardo Henrique, \& Arbex, Flávio Ferlin. (2018). Risk factors for tuberculosis: diabete, smoking, alcohol use, and the use of other drugs. 44(2), $145-152$.

Teixeira, Francine, Raboni, Sonia M., Ribeiro, Clea E. L., França, João C. B., Broska, Anne C., \& Souza, Nathalia L. S. (2018). Human Immunodeficiency Virus and Tuberculosis Coinfection in a Tertiary Hospital in Southern Brazil: Clinical Profile and Outcomes. https://doi.org/10.1177/1178636118813367

Vadlapatla, Ramya Krishna, Patel, Mitesh, Paturi, Durga K., Pal, Dhananjay, City, Kansas, \& City, Kansas. (2015). HHS Public Access. 10(4), 561-580.

World Health Organization. (2015). TB and HIV co-infection diagnosis, treatment and statistics. retrieved from TBFactstbfacts.org > tb-hiv. 